Article

\title{
Sensing and Longing for God in Andrey Zvyagintsev's The Return and Leviathan
}

\author{
Denys Kondyuk \\ Ukrainian Evangelical Theological Seminary, Kiev 04075, Kvitka Tsisyk 57, Ukraine; dean@uets.net; \\ Tel.: +38-097-891-60-31; Fax: +38-044-401-82-42
}

Academic Editor: Joseph Kickasola

Received: 22 March 2016; Accepted: 16 June 2016; Published: 25 June 2016

\begin{abstract}
This article explores apophatic ways of presenting God (the Other) in two films of Andrey Zvyagintsev. The lens for this analysis is the phenomenological theology of John Panteleimon Manoussakis, using the following concepts: (1) God as personal Other; (2) the relational nature of God's self-disclosure through prosopon; (3) God as revealed in space/sight; (4) God as revealed in hearing/time; and (5) God as revealed in touch/self-understanding. This analysis, pursued through close examination of Zvyagintsev's The Return (2003) and Leviathan (2014), demonstrates the relevance of Manoussakis's theology to the study of religion and film, particularly in its sensual and experiential themes and emphases.
\end{abstract}

Keywords: icons; relationships; absence; theological aesthetics; interpersonal relations; theophany

\section{Introduction}

The Russian director Andrey Zvyagintsev stands as one of the most prominent contemporary film artists addressing the role of the transcendent in the everyday. His films tell the stories of the daily life of common people and do not, generally, refer directly to God or theology. For this reason, there is a broad range of interpretations of his films, and some do not see them in religious terms. However, Zvyagintsev clearly defines himself as a Christian without declaring his denominational identity ([1], pp. 323-25), and he consistently addresses transcendental questions through subtle means, indirectly referring to the Christian tradition in each of his feature films. Thus, we might see him standing in the "apophatic" tradition of theology and religious art making: expressing God and truths about Him through thematic and stylistic patterns of negation rather than concrete assertions or representations. These patterns represent the Divine-human relationship through the prompting of desire for such relationship. The relationship is felt to be essential, and so it stands as a type of experiential theology. Such patterns of negation run through all his films, but they are most clearly seen, heard, and "felt", in his breakout film The Return (2003) [2] and his more recent Leviathan (2014) [3], which we shall analyze.

First, however, these patterns-which are both thematic in the narrative and experiential for the viewer-are best understood through a theology of relation. The Orthodox theologian John Panteleimon Manoussakis's phenomenology of prosopic relations foundationalizes the paradoxical Presence-through-Absence that lies at the heart of Zvyagintsev's apophatic cinema.

\section{Manoussakis}

Manoussakis suggests a way of describing God that could be applied to film analysis, and builds on the phenomenological tradition of Edmund Husserl, Martin Heidegger and Jean-Luc Marion. In addition to the transcendent, ontological and doxological reductions these thinkers have proposed (regarding things themselves, being, and givenness, respectively ([4], p. 26)), Manoussakis proposes a fourth phenomenological focus upon prosopic relations. That is, phenomenology should be seen as 
relational, with no priority of the experiencer over experienced, or vice versa; that is, the relationships are primary and constitute their existence as relational infinity ([5], pp. 1-2; [4], p. 24). Likewise, he suggests that we should see God in such personal, relational categories. Indeed, in this context, God is the Other and the source of all relatedness ([4], p. 27).

\subsection{Relational Theology}

The moment one perceives oneself in relationship, and defined by it, is termed exaiphnes ([4], pp. 27-28). Manoussakis also defines person as prosopon, uniting this definition to the event of God's incarnation. Thus, he states:

When we strive to redefine the person phenomenologically as prosopon, namely, as this coincidence of the phenomenon (essence) with phenomenality (existence), that is, a hypostasized ek-sistence, we have in mind nothing else but the event of the Incarnation. Pace Heidegger and St. Thomas, we do not think that God's self-hypostasizing of His existence should be mutually exclusive of man's potential of transcending his nature by choosing to be (and become) who he is. If man can exist as a person (which is what Heidegger claims concerning the Dasein), that is because God (the person par excellence) became man ([4], p. 31).

This prosopic redefinition of personality is consistently illustrated in Zvyagintsev's films: his characters are challenged to be hypostasized by their encounter with God as the ultimate person (prosopon). However, there is much more to be said, as artworks, such as films, do more than "illustrate". Indeed, in his book, God after Metaphysics, Manoussakis refers to different paintings and forms of art to assist his theological/phenomenological approach, and uses the senses of sight, hearing and touch to articulate his understanding of the knowledge of God. These senses serve to establish some important categories of relation to the Divine-spatiality, time and self-awareness through interpersonal perspective-and we will use these three main categories in our film analysis ([5], p. 4). These categories, accessed through sight, hearing and touch, respectively, are possible because they are seen in the context of interrelatedness and are the only ways for a human being to experience the transcendental Other. In other words, Manoussakis relates sight, hearing and touch to our experience of interpersonality in space, time, and two-way intentionality and self-awareness (because of being-seen-by-the-other/Other) ([5], p. 24). The work of Zvyagintsev can be profitably seen through the Manoussakis's lens of interpersonal relations, as it reveals the intentional, relational dynamic at the heart of his aesthetics, and highlights the his themes of struggle for self-identity and meeting the other/Other (being met by the other/Other).

In order to view Zvyagintsev's art from this perspective, we will evaluate his films with focus upon the transcendental encounter experience (through ordinary life). Zvyagintsev articulates directly that he admires the paradox of reality; that is, the unexpressed complexity and overlap of time, events, and the experiential, interpersonal nature of the ultimate reality itself ([1], p. 149). Thus, he strives to express the enigma of our experience of events and our being amid our deeply rooted interpersonal relations and our longing for the other. As mentioned, this attitude has strong correlations with the apophatic theological tradition, long admired in Orthodoxy and most brightly articulated in works of Dionysius the Areopagite, which emphasize the inexpressiveness of God, yet express a constant yearning for Him [6]. Yearning for the Other and mysterious presence of the infinity within creation is important to both the apophatic tradition and to Zvyagintsev's art.

\subsection{Manoussakis's Methodology in the Context of Contemporary Phenomenological Film Studies}

Manoussakis's phenomenologically-driven theology may be profitably aligned with some contemporary studies in phenomenology of film and religion, as a means of broadening perspectives on film and religion. For instance, in her presentation of phenomenology of film analysis, Vivian Sobchack points out that we experience the transcendental (which, for her, is an indirect experience of the 
invisible) through the immanent (the visible that we experience directly) ([7], p. 295), and that they are correlated closely in our bodily life experience [8]. It is precisely the film form that permits the audience to experience interpersonal phenomena subjectively and exteriorize its own subjectivity ([7], pp. 11, 136-38). Though Sobchack concentrates on the relation between film and its viewer, she points out that film watching could be experienced as "being-in-front-of-another" and our subjectivity could yield intersubjective experience with the film. Manoussakis's thesis helps to theologically locate this "being-in-front-of-another" moment within a film body.

Joseph G. Kickasola argues that transcendence in films may be offered as invitation to something beyond the presented (the invitation that could be rejected, which also presumes interpersonal involvement) ([9], pp. 44-45). We can phenomenologically analyze films partly through a spiritually suggestive polysemy, where films broaden their meanings or present multiple meanings (it is almost as if a spiritually-driven film context can make ordinary objects transform into something other) ([9], p. 72). He also mentions Martin Buber's interpersonal emphasis in phenomenology of the Transcendent, which appears in-between "I" and "Thou", correlating it to the major points of Manoussakis proposal ([9], pp. 57-58). Thus, Kickasola also supports the possibility of film as transcendent experience, based on focused stylistic/aesthetic strategies and story cues, that invites the viewer to the transcendental experience (as experience of the other/Other).

The importance of empathy in phenomenological film analysis is recognized by many authors, and often correlated with haptic knowledge. For instance, art historian David Morgan emphasizes the importance of empathy and correlation between seeing and touching in religious art and religious experience [10]. Another aspect of Manoussakis theses could be seen in a parallel between his idea of self-knowledge through co-suffering/empathy and Jennifer M. Barker's approach to film analysis. She states that film experience is always a co-existence of distance and proximity, and the viewer is involved interactively into the film through ones empathy ([11], pp. 12-13, 73, 75). She also thinks that meaning of the film evolves in a bodily encounter of a viewer and a film body, so Manoussakis emphasis on "embodied" experience of the other/Other and ourselves could be correlated to film watching ([11], pp. 15, 19). Barker also notices the interpersonal nature of haptic film experience:

...[T]ouch is not about ownership or complete knowledge of the other, but is truly intersubjective. Just as, in the exchange of glances with an other, we can see ourselves seeing, in the contact of our skin with another's, we can feel ourselves feeling. We feel ourselves as if for the first time in that moment, and as if from an external "point of touch" ([11], p. 35).

This correlates directly to the interpersonal methodology of Manoussakis and to his idea of haptic self-perception. His films are occasions for participation: his film characters and film viewers can experience aggression or loving care that create the possibility of co-suffering. Or perhaps we will experience doubt and rebellion, and trace all the power struggles and violence in Leviathan [3], for example, as the quest for self-identity. In that film, the Mayor is filled with doubts about himself and God's view of him and it actually pushes him into more radical violence, and the audience may see a negative kinship here in its own failure to empathize. On the other hand, the successful experience of loving touch gives the character and film viewer possibility to experience love that is shared (to share the experience that leads to healing or pleasant personal encounter, so the film body is embraced). The meeting experience of a viewer does not happen automatically, but requires personal involvement and willingness to connect ([11], pp. 94-95, 160). This correlates to Manoussakis idea of kairos and exaiphnes as interpersonal experience of time, which requires one response and is discovered by it.

These parallels show an affinity between Manoussakis's thoughts on the phenomenology of relation and contemporary film analysis, and allow us to introduce his phenomenological approach into film studies (especially in the context of transcendental experience and religious experience). As mentioned, the patterns of negation, as Zvyagintsev expresses them cinematically, paradoxically engender Divine-Human relationship through the prompting of desire for such relationship. Zygvanitsev's cinematic style, then, may be profitably analyzed through Manoussakis' categories of space, time, and self-perception, as they extend from the perceptual terms sight, hearing, 
and touch. We will trace these themes throughout The Return (2003) [2] and the more recent release Leviathan (2014) [3].

\section{3. "Seeing" through Not Seeing: Visuality, Negation, and Space}

One of the approaches to describe God, according to Manoussakis, is "sight", but how can one see God? For Manoussakis, this "sight" is, actually, a spatial experience of God, but a very peculiar one; this seeing is not so much an experience of vision, or an analysis, but a meeting. Seeing God, for Manoussakis, is encountering his piercing gaze and suddenly being found in relationship with the Other ([5], pp. 106-8), but this encounter is less direct than in human relations. Manoussakis states that we can only experience God through creation, and the way He is presenting Himself is not a revelation of his essence. It is a revelation of His personality and it represents the very fact of being seen and being able to see ([12], p. 84). It calls to mind Jean-Luc Marion's idea of "excessive phenomena", which can be sensed in a personal encounter, but cannot be completely comprehended [13]. Manoussakis even states that God could actually be seen everywhere in daily life, but we need to first experience His unexpected presence to grasp it. Only then will we feel "being-in-front-of-another" ([5], pp. 19-24, 34). This phrase may sound obscure, but it seems that he is indicating not a concept or thing, but a personal experience that serves as a channel for God's representation.

\subsection{The Return}

The Return [2] presents the story of two brothers who unexpectedly find themselves on a trip with their father, who has suddenly reappeared after years of mysterious absence. During the trip, he appears to be hard on them and does not care much about their emotions and reactions. Ivan, the younger brother, seems to confront him all the time and does not trust him. Andrei, the older brother, seems to be more open, but is easily influenced by Ivan's attitude. The conflict grows to the point when Ivan is almost ready to commit suicide, but then the father dies. He falls from an old watchtower on a desert island. After the father's death, the attitude of the boys suddenly changes, and they suddenly discover/realize both his love and the counter-intuitive logic of his previous expectations of them. They try to save the dead body of their father, but the boat that was carrying it sinks before they could remove it, and so, their father is gone again, this time for good. Now he can be present only in the lessons that they learned from the trip.

Zvyagintsev provides a hermeneutical key through biblical and artistic references that enrich the narrative and enlarge the scope of what is presented. For instance, it is implied, almost from the beginning, that the father figure is related to Christ (and therefore represents God) by direct reference to Mantegna's Lamentation over the Dead Christ painting, Figure 1. Indeed, their first look at the father is presented as a frame recreating the Mantegna's painting, Figure 2. Through this connection, we know, or at least could expect, something transcendental from the father character.

It is also paradoxical that boys could not recognize their father and need to check his old photo hidden in the illustrated Bible on the page that shows the sacrifice of Isaac (a scene that will be literally replayed between Andrei, the Father, and Ivan at the end of the film ${ }^{1}$ ). Though the father "returns" in the plot, the whole movie is, actually, the boys' return to their father, to an acceptance of the father-son

1 If the Mantegna painting suggests that God is revealed in death (and, presumably, resurrection), the Bible illustration suggests the encounter with God can be terrifying, and deliverance may only come unexpectedly. In the film's most climactic scene, Andrei screams that the father wants to kill him, provoking the father to grab an axe, hold it over him, and ask if he "really thinks so". And, yet, thematically, it is Ivan who is in danger of actually being "sacrificed" (ready to jump from a watchtower) and eventually saved by the Father's efforts. This may remind us of Søren Kierkegaard's Fear and Trembling, where he states that Abraham first appears as a murderer, not a hero of faith, but the story requires a perspective of faith to be understood properly. Indeed, the whole story could be seen as a passion event of Abraham, bringing even more parallels to Christ into this context [14]. The Father, perceived as a monster, is truly a hero. Therefore, visual citations of death and sacrifice in religious art suggest we view the boys' experience as an experience of God. 
relationship. True recognition of the father as a father figure comes to Ivan at the moment of the deadly incident, described above, not when he sees his photo in the Bible.

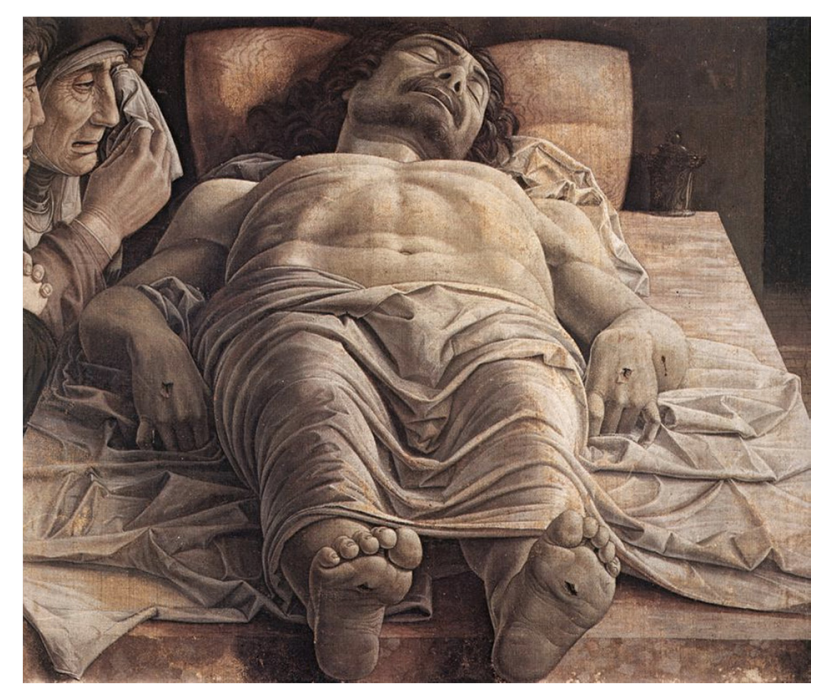

Figure 1. Andrea Mantegna "The Lamentation over the Dead Christ" (ca. 1480), Pinacoteca de Brera, Milan, Italy (Tempera on canvas, $68 \mathrm{~cm} \times 81 \mathrm{~cm}$ ).

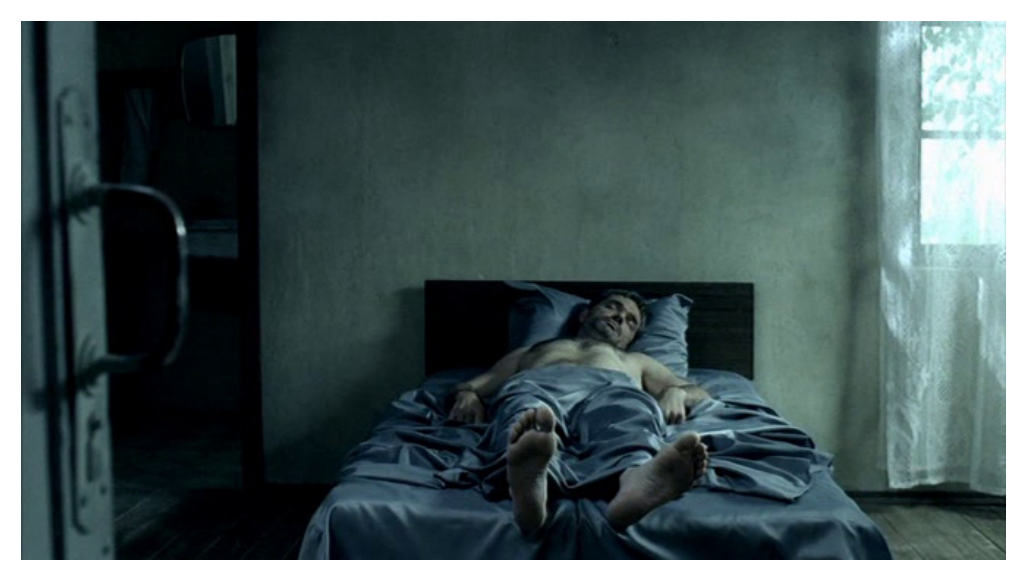

Figure 2. The Return (2003).

This is the sort of negation that reveals the always-present theophany Zvyagintsev's films. It is crucial to understand that, throughout most of the film, the boys do not experience their father as the presence of the other/Other. This presence is only disclosed, paradoxically, through his death. To be more specific, the first time the boys see their father he is sleeping, and they cannot recognize him, but when he falls to his death, they discover him as their father. The irony is the fact that it is through the closed eyes of the father-in his sleeping body, an obvious reference to death, and later in his closed dead eyes-where the boys discover the experience of meeting someone beyond their comprehension, the Other, Figure 3. Indeed, dead or sleeping people play an important role in most of Zvyagintsev's stories, and they can be seen as a quite literal image of lost relationships, as the lost opportunity to meet the other/Other. It seems Zvyagintsev deliberately emphasizes the enigma of the father figure, thus illustrating the inability of people to comprehend God, and when an interpersonal experience of the Other is experienced, it is only through a kind of interruption that we can appreciate, and in a sense, discover it (and, this leads us to an interpersonal experience of time, to be discussed in the next section). 


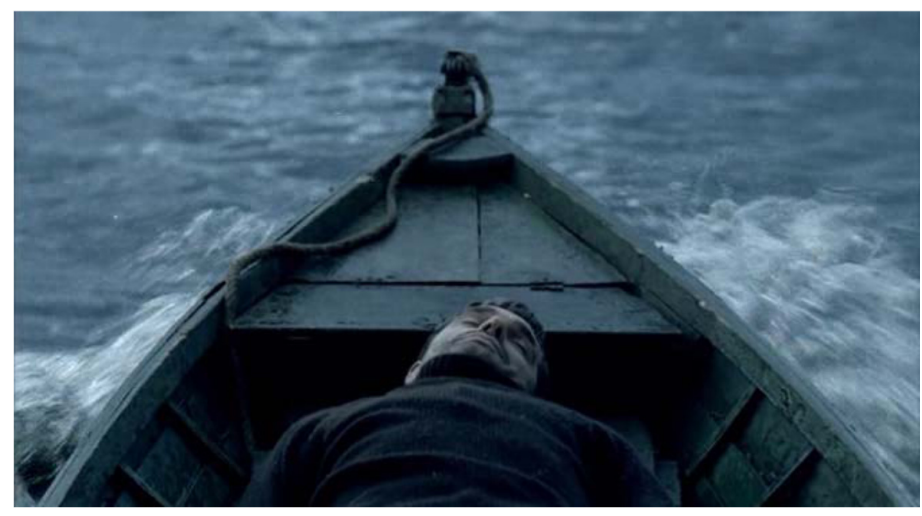

Figure 3. The Return (2003).

Zvyagintsev also uses the absence of eye contact and death as a visual means of presenting transcendental relation, as if to illustrate a passage from Manoussakis: "Could it be, then, that I can finally 'see' God even if it is with eyes shut?" Though he speaks of our lack of eye-contact, we can still see that the paradox of meeting is beyond physical eye contact ([5], p. 22). Throughout the film we see numerous instances where characters' eyes should ordinarily meet, but simply do not, Figure 4.

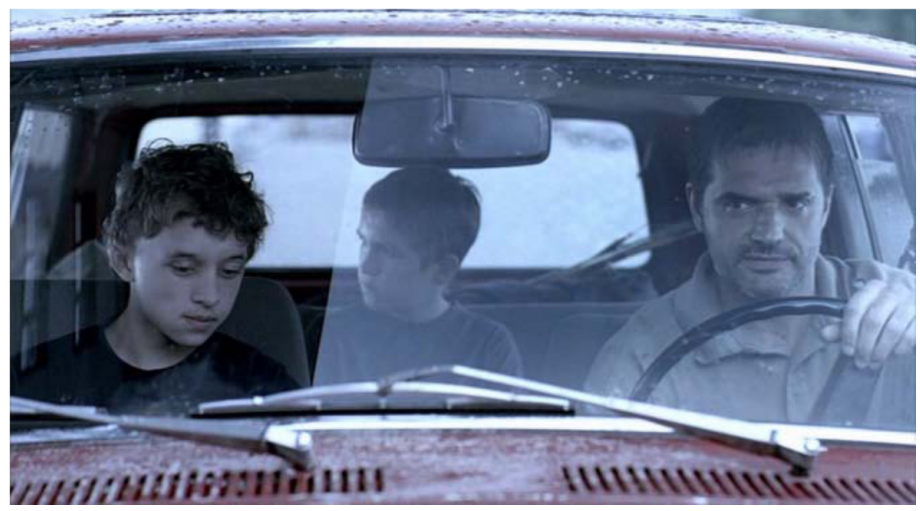

Figure 4. The Return (2003).

It is also remarkable that both the father's appearance and disappearance in waters are out of the boys' control. The opening shots of the film show an empty, sunken boat; it is only later that we discover this is the boat in which the father's body sunk, but here there is no body to be seen in the beginning, Figure 5. This sort of mystery and incongruity suggests a more theological interpretation of the father.

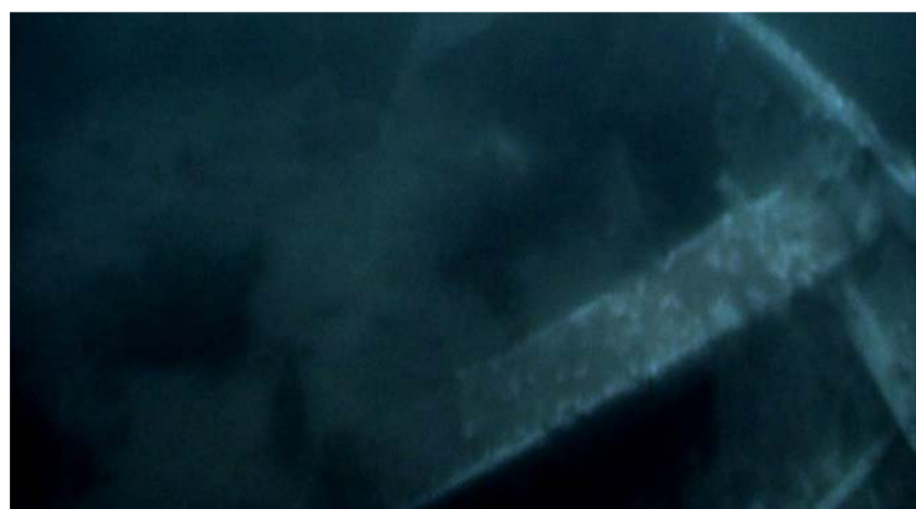

Figure 5. The Return (2003). 
There is a similar pattern of negation in the final slide show of Andrei's photos from the trip (that can be seen just before the final credits, Figures 6 and 7), where there is no single picture of the father from the trip and only a couple from the past, similar to the one they saw in the Bible. He is inexpressible outside of the boys' personal experiences and memory. It seems that there is almost no proof of the father's existence and we nearly think that it was all a parable and they traveled by themselves the whole time, yet it is here, for the first time, that boys know their father and remember him.

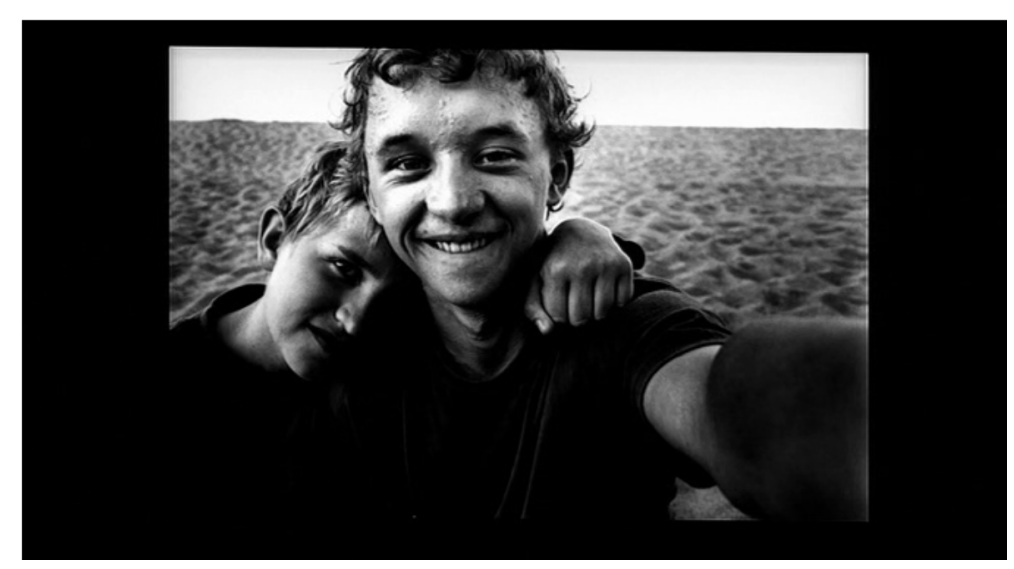

Figure 6. The Return (2003).

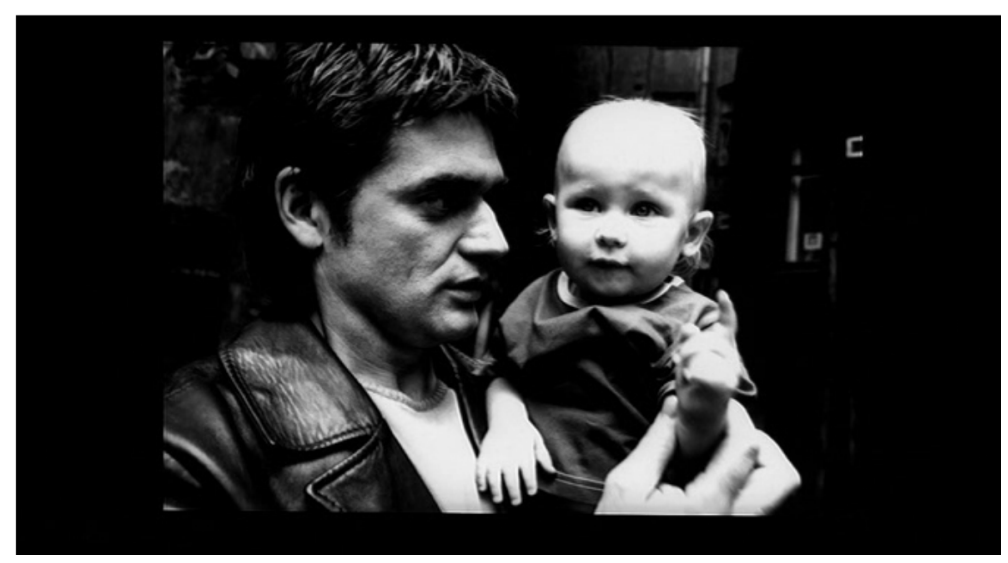

Figure 7. The Return (2003).

As mentioned, the pattern of sight/non-sight also correlates with Manoussakis's conception of space, but how? In what way does Zvyagintsev present the Other spatially? The conflict and resolution of the relationships are mainly presented through travel and movement. Therefore, physical space depicted in the film is used to represent the characters' physical travel, but also their personal journeys, that is, the "distance" between being seen by the other and being able to see the other/Other in return. Travel is a figurative movement of Ivan and Andrei toward their own identity. It is not a coincidence that in the beginning of the film Ivan is chasing Andrei, but later we see them change places, as if it were Andrei chasing Ivan, and they run together home to discover their father (in a scene that illustrates the whole film). Travel could be an expression of finding the Other, but actually it is because of the apparent obstacles and failures in this journey that the meeting becomes possible.

In this light, water is also an important element (or even a "character") in the film. It is with the image of water that film begins and it is water that consumes the father's body in the end, Figure 8 . It is Ivan's fear of jumping into the water from a diving board that, in a way, leads to the tragedy. Water is also present in the brothers' constant desire to go fishing, and in the rain that drives away the father 
and sons from the watchtower for the first time on the island. It is also raining when Ivan is left alone to fish, when the car is stuck, when they try to drive further, and when they travel to the island for the first time. Rain is presented as a challenge, as something to overcome. Crossing the water also relates to the change in the boys' attitude toward their father. Water is used as an obstacle for truly meeting the father, yet it is also the travel back from the island that gives "birth" to a new kind of relationship between the brothers and drastically changes their attitude toward the man they both call "Daddy" in the end. Thus, water illustrates the purifying power that goes along with personal struggles and discoveries, but it also marks spaces and obstacles that we see and must overcome. We can conclude that it is through physical obstacles and the loss of contact with the Other that this Other can be fully recognized in The Return [2].

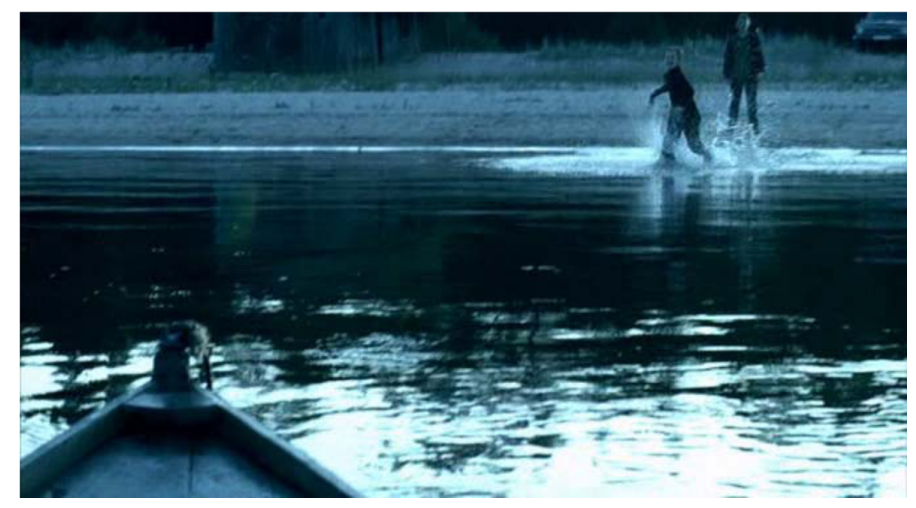

Figure 8. The Return (2003).

\subsection{Leviathan}

Leviathan [3] is similar to some of Zvyagintsev's mid-period films (such as Elena, 2011 [15]), in that, on the surface, it may look like just another harsh story of conflict between different people. Nikolay, is a land owner, and the local mayor wants his land and uses a court decision to take it. Nikolay invites his friend, a lawyer from Moscow named Dimitriy, to help. However, in the process of fighting for his land, his wife commits adultery with Dimitriy, and later Dimitriy escapes after being threatened by the mayor, and his wife Lilia commits suicide. On top of that, Nikolay is accused as a murderer of Lilia, goes to jail and loses everything (even his son is taken by another family). Yet, all of Zvyagintsev's films raise questions about the nature of relationships between people (and with God). It would be inappropriate to see the film as solely political commentary, as if it were only about the Orthodox Church's collusion with state authorities, for instance. Leviathan [3] concentrates on social issues, but also underlines the human inability to see the other and to love the other. As in all of Zvyagintsev's film, the family here is troubled. Nikolay thinks that his main problem is the danger of losing his house, but he misses the fact that he is losing his relationships with his wife, his son and his good friend. He does not know how to face the other, and only losing everything brings him a step closer to reaching this understanding.

At one point, it looks as if Nikolay is looking for God, but he settles for vodka. Indeed, alcohol and drunkenness play an important part in the visual presentation of characters' inability to communicate. While drinking is supposed to help people open up, it often functions to reinforce all of their loneliness and interpersonal problems. This serves as an illustration of an artificial meeting with the other. Likewise, sexual relationships also serve as a substitute for a real encounter. Both Dimitriy and Nikolay are happy to have sex with Lilia, but neither of them wants to understand her pain and questions. It seems, in general, that the physical experiences of the characters in the film tend to be a substitute for personal relationships. Nikolay never tries to talk seriously to Lilia or Roman, or even Dimitriy. He is happy to speak about superficial things, until his life collapses. It is ironic that he questions God for his struggles, not seeing his own inability to communicate. Thus, we see here, again, the negative 
thematic pattern of not seeing numerous invitations—visual and interpersonal—to relationship with the other/Other.

This thematic pattern is visually experienced, in part, through the ironic use of religious imagery. Leviathan [3] is filled with icons, statues and questions that invite one to encounter God, but people are mostly too busy serving themselves and living their lives as if there is no God to notice. As we already noticed, Zvyagintsev is clearly influenced by the Orthodox apophatic and spiritual tradition, and orthodoxy regards icons as being not just images but personal invitations for real communication with the person depicted [16]. Indeed, it is remarkable that we see so many small icons throughout the film, in addition to the big The Last Supper icon at the patriarch's residence during the mayor's first visit, Figure 9, and a statue of the crowned Jesus at their second meeting. We also see an ironic juxtaposition in the little icons in Stepanich's car next to nude girls stickers, Figure 10. Finally, there are many icons in the Church at the end of the film that watch us with a penetrating gaze. However, it seems that not many people are reacting to this gaze that we see occasionally, and Stepanich's car stickers also illustrate that attention is directed not to meet God, but to everyone's individual depersonalized passions. It seems icons become "idols" in themselves for those who are unable to see personal invitation behind them, Figure 11. To recall Manoussakis, everything could lead us to experience God if taken interpersonally, but, conversely, even religious art or acts can become "idols" if depersonalized; in this light, idolatry is a symptom of depersonalization.

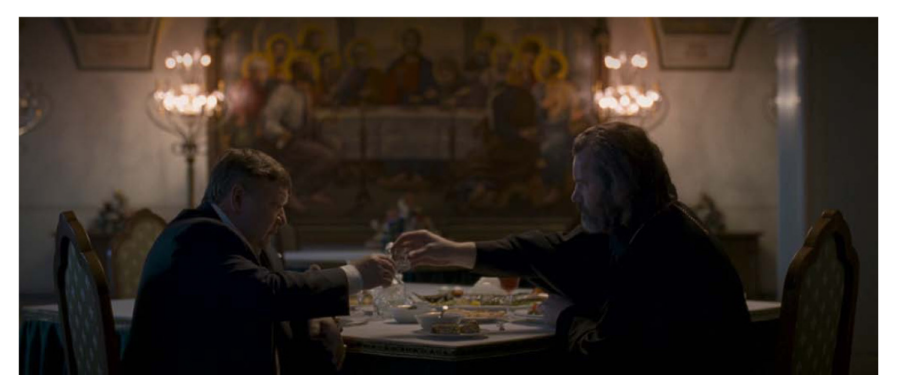

Figure 9. Leviathan (2014).

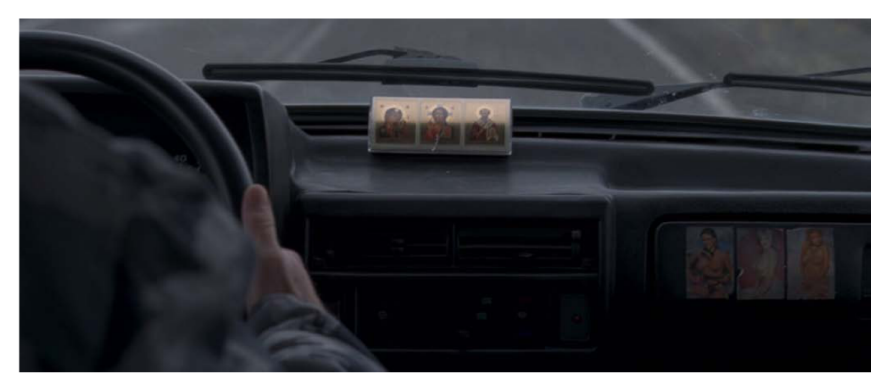

Figure 10. Leviathan (2014).

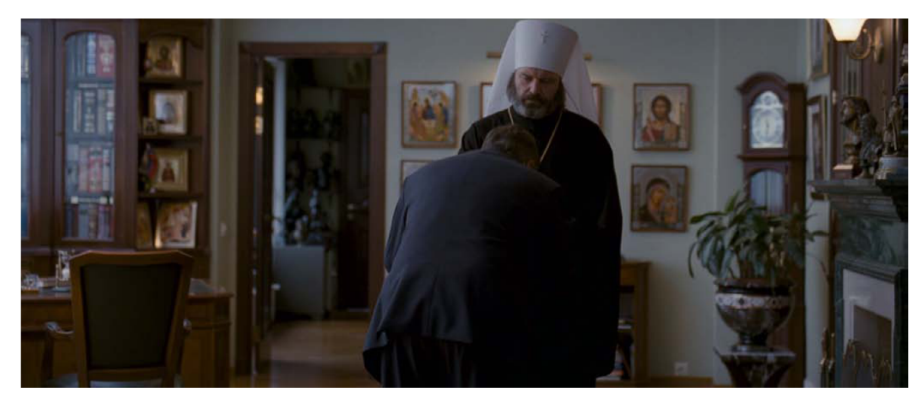

Figure 11. Leviathan (2014). 
As its title suggests, Leviathan [3] may also be seen through the lens of the story of Job (cf. Job 41:1), as was noted by Denis Bekkering [17]. In addition to many references to this biblical narrative, the film also presents God through the nature and the depiction of whales. They in some way correspond to the biblical Leviathan, but even their immensity is weak in view of the whole creation and time. Thus, we see a whale before the disappearance of Lilia and we see whale's bones when Roman runs away from home, Figures 12 and 13. In this way, whales appear before big losses, they illustrate the power of separation. Yet, they are presented as limited and passing. Nature serves as a vast background against which the local story seems small, and not as fully understood as it may first appear. There is a space for God on top of what we see during the film, and the beginning and the ending images of Leviathan [3] seem to point to that too: the "eternal" sea and mountains show how all of us are tiny characters in light of the world's history, and how hard it is to judge any local situation without considering that broader account. This returns us to the biblical story of Job, wherein Job's questions regarding human suffering are answered, by God, through a description of Nature's immeasurable complexity and enormous scale.

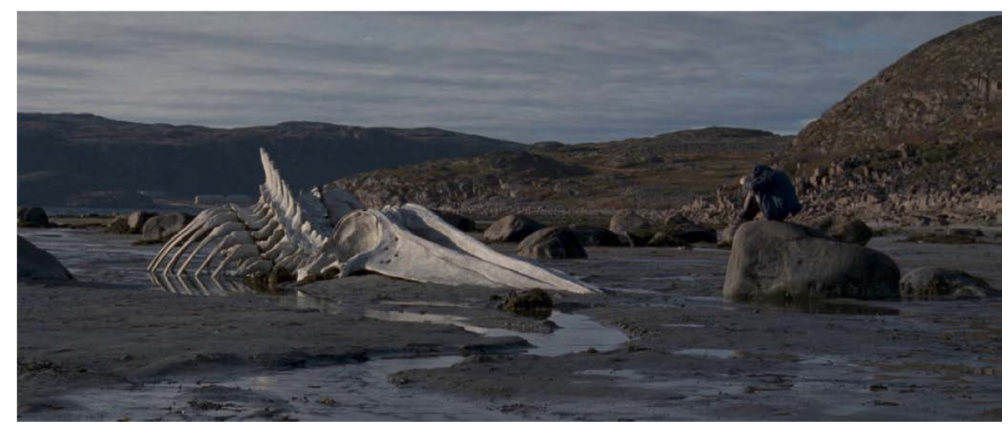

Figure 12. Leviathan (2014).

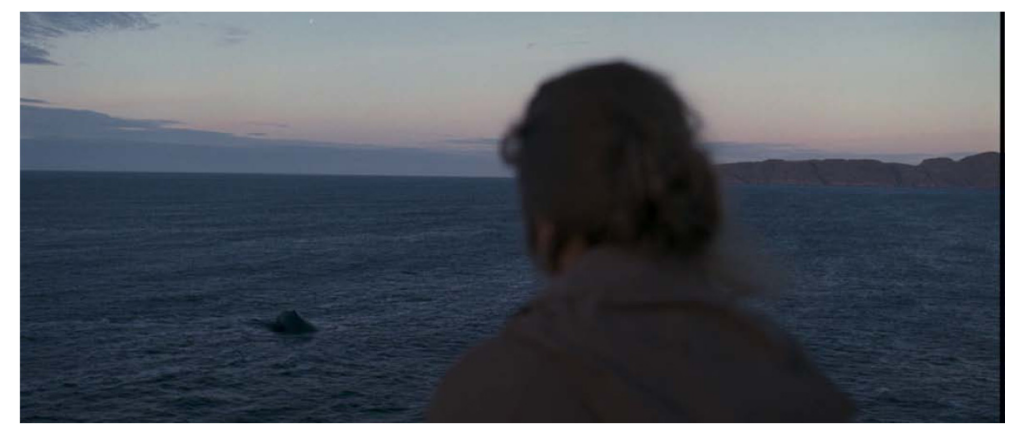

Figure 13. Leviathan (2014).

\section{4. "Hymn": Hearing and Time}

Manoussakis mentions that when we praise God with a hymn we do not just inform somebody, but we learn from ourselves, from the act of worship itself ([5], p. 106). Sound and speaking are bound to temporality, so we will analyze sound and temporality together, but Manoussakis insists we recognize two different temporalities: "Language and thought are chronic-the 'language' of God, on other hand, follows an entirely different temporality, that of kairos" ([5], p. 104). It means that our experience of time tends to be a lasting continuity, which creates a history we may describe, but kairos is an experience of timeless perspective, a kind of enlightenment that breaks the continuity of chromos and unites past, present and future (something also called Eucharistic experience) ([5], pp. 58-59). Again, this experience of time relates to God only if we take this sudden experience as manifestation of interpersonality and reversed intentionality in time, as Manoussakis describes: 
When this happens, when my perspective is countered, inversed, returned to me, I am no longer the privileged subject that establishes and constitutes the objectivity of the world (the thinghood of the things), but merely a dative; I become this "to whom" the world, as the world-to-come, is given. For only then can there be a world given, when I make myself available as a receiver, as gifted (l'adonné) with the gift of givenness ([5], p. 67).

Thus, it is not we that expect a phenomenon or even the other/Other, but this other/Other that challenges us to discover ourselves.

This experience is possible when we communicate with God and allow a point of time when He may appear, and that is what could be called a hymn. However, a hymn is not created by us alone. It is something we are borrowing, that we share with others, and makes participation possible. Hymnic experience and language is a kind of borrowing of somebody's experience of God in order to enact it here and now. It is through participation with those who are open to the other and God, where we discover the hymnic (which transcends singing).

Of course there are ways to depict God in time as continuity (as chronos). This is how historical movie epics usually depict God in movies. Yet, there is another way of representing the infinite in time. There could be an insightful moment that suddenly introduces God into a coherent story (a moment of a sudden call), but this moment could not completely belong to the flow of a story (and even look as something embarrassing to a viewer). It both fits, but also doesn't fit the storyline that is depicted (it is something said or done by the characters, but it turns to, or turns against them). An example here is the sudden return of the Father in The Return [2], and his awkward insertion into their daily routines.

According to Manoussakis, the inability to describe a certain time experience is related to the nature of Eucharistic time, which cannot be properly described in terms of sequential temporality, and only be understood as kairos through a vertical break in time experience ([18], p. 79). Also, the experience of an unexpected theophany (a sudden revelation or call from God), which cannot be properly described in typical categories of time, may be expressed with the term exaiphnes ([5], pp. 64, 69-70).

This is what some moments of Zvyagintsev's films reveal. In one of his interviews, he explains that he makes his art with the idea of myth in mind ([1], pp. 148-52, 275-76). In his understanding, myth portrays time as coexistence of timeless experience with our usual experience of time in actions and relationships that are presented in a piece of art. Zvyagintsev's idea of myth is closely aligned with Manoussakis' idea of double time as kairos and exaiphnes, so we can profitably analyze his art through the concepts of hymnic language and of Eucharistic time. As with vision, the apophatic patterns here are abundant: "language" and "time" that exceed our speech and temporal experience, as well as words and "call" that are never physically heard, but still resonate.

\subsection{The Return}

This whole film is built around days of the week, starting from Sunday (in Russian, this is the same word as is used for resurrection) and ending on Saturday. Time is presented in the film as making a full week circle (as if the story is really about all time, not just the week), so we meet the father as a resurrected Christ on Sunday, and then he dies on Friday and disappears in the waters on Saturday (as if consumed by death). It is also important that Ivan opens his illustrated Bible on pages with the creation story too, before finding a family photo. Time is seen in the film as global, cosmic, and creative, combining stories of creation, salvation and the daily life of the main characters.

Ivan suddenly identifies his father at the moment of his fall and consequent death; this is his exaiphnes. This is also a moment that changes his attitude towards his father, and he starts calling him "Daddy". He voices the identity of himself and his father in reaction to his father's death. The same change could be attributed to Andrei (so as it seems to be his kairos and exaiphnes too), too, as he is suddenly transformed into a leader; he starts to act and talk just as his father did when he was still with them, so he really "arrives" at his identity as an older brother in this moment, leading the younger Ivan. 
The boys started to act accordingly only after re-evaluating their experience with their father through his act of sacrifice (though it looks like an accident). The fall becomes a gap in time that creates a new perspective on everything and allows for a "mythical" experience of time (in Zvyagintsev's words), and suddenly chromos becomes kairos. This retrospective experience of time (when all that was shown gets completely reversed in meaning after a certain moment of epiphany) is important for most of Zvyagintsev's films. Likewise, he regularly presents time in the Eucharistic categories of Manoussakis, where the continuity of time is suddenly interrupted by the experience of the other ([18], p. 80).

Andrei's sudden emulation of his father suggests that meeting God is co-ordinate with participation in his acts. It is also by participating with the other and being directed to the other that we experience the hymnic language/experience. Yet, it is the father's love that brings this about, not by force, but mysteriously through the boys' own choice. Therefore, their experience could be categorized as hymnic, though they do not sing or pray, because by receiving the words and acts of the other and making them their own they simultaneously experience reality through the father's perspective. They actually meet him by participation with and openness to him. The words and acts of the father become their hymn. His insistence on calling him "father" throughout the film, despite their resistance, becomes their own vocabulary in the end.

\subsection{Leviathan}

Leviathan's [3] time is portrayed in two ways: the static time of the beginning and the end frames a kind of circular life experience of the main characters. We could suggest that God intervenes into this reality through the silent faces of icons and statues and through marvelous nature, which surrounds the drama. Nikolay and Lilia expect God to intervene somehow, but it looks as if it is not going to happen. It seems that the mayor and the bishop do not have to suffer for their perverted version of Christianity (e.g., they take, in a corrupted manner, Nikolay's property to use it for a Church building, destroying his life and family). Life continues as usual. The despairing circularity of life is emphasized by Lilia's work at a fish factory, where she depressively watches a conveyor work, thinking about her own way of life. Leviathan [3] is similar to the story of the book of Job, but there is no clear resolution in the film, in contrast to the face to face with God experience of Job. Nevertheless, as we could hear from Stepanich, there should be a historical perspective to judge people's lives, so it could be applied to the story shown, too.

In the end, there is a deliberate irony experienced in the audience's experience of the hymnic: the word of God through hypocritical men of dubious character. The bishop, in spite of himself, offers a prophetic word that he did not write (another instance of "borrowed" speech that transcends the individual as liturgy), Figure 14. Through it, he brings forth the judgment of God that is "not in power, but in truth, not with force, but with love, not with treachery, but with wisdom ..." The corrupt mayor makes religious comments as well: "This is the Lord and he sees everything". There is a deeper irony here, of course: almost all words that are said by the bishop could be reversed and be a judgment on those who gather at the Church building, which has been built on lies and death. And yet, the faithful can still hear the truths that transcend human performance. The preaching scene creates the possibility of a hymnic experience for those who hear, even if the bishop does not hear his own sermon properly himself, for fear of judgment. The preaching creates space for real worship, repentance and a personal meeting with God. It brings some hope and leaves the possibility of conversion for those who can hear it (and it seems that another religious character, the local priest, does see and hear the preaching properly).

Thus, in Leviathan [3] we do not see a clear resolution and meeting, but we can see the possibilities of kairos not from a perspective of a certain character, but as viewers that can see and hear the whole story (in a very similar manner to the Book of Job, where it is the reader that knows what is really happening, but not Job himself). 


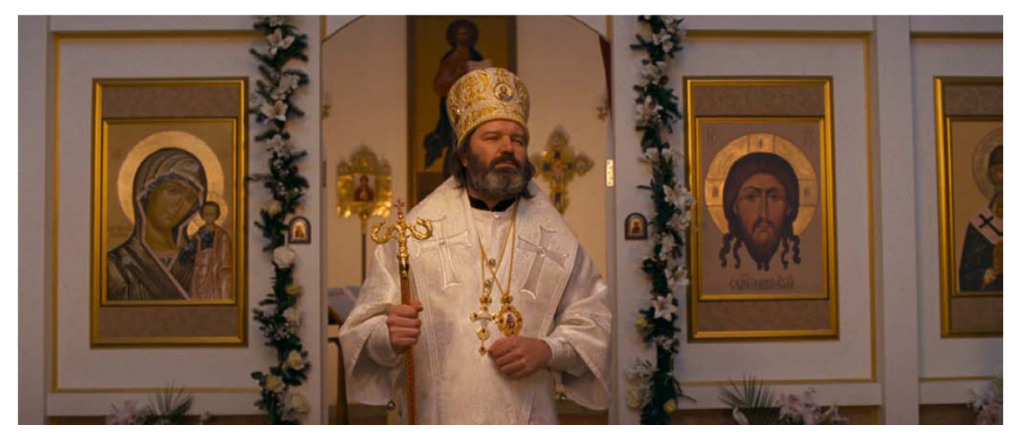

Figure 14. Leviathan (2014).

\section{5. "Touching Itself": Self-Perception and "Haptic Knowledge"}

Manoussakis articulates the a crucial point concerning self-perception and the concept of touch:

When, then, the soul is compared to the hand, much more is said about the soul than what, we might, at first glance, think to be the case. For in "touching" the things it seeks to know, the soul-hand is also "touched" back by the world. As "touched", in the act of comprehending, the soul becomes aware of itself. It becomes aware of itself as a soul that "touches" the world. This self-awareness achieves the impossible-for it could be said that in some sense the soul, aware of itself as a soul, is touching itself ([5], p. 127).

He actually states that knowledge of ourselves starts in our relationship with the world and others. That could be applied to film analysis on the level that we may evaluate the story and its characters as to how they grow in self-awareness (using their senses). All the senses that Manoussakis evaluates are seen in the context of encountering and discovering the other/Other. It is actually continuation of spatial and temporary experience, placed in the context of interpersonal self-awareness. Basically, it is not so much about what causes our experience, but the context for it (therefore, the term "haptic" is applied in a rather symbolic sense). Actually, self-knowledge is always a bodily experience, and it is always interpersonal, and based on our ability to sympathize (suffer-together-with the Other) ([5], pp. 140-41). In our film analysis, this self-perception is a byproduct of the experiencing the other/Other, through the senses mentioned before, but experiencing the other/Other in love, or as love. Of course, film does not allow us to physically touch anything, but the cinematic imagination offers haptic experiences we can analyze.

\subsection{The Return}

The self-awareness of the boys in The Return [2] grows through experience with their father, but is fully revealed at his death. Ivan suffers his fear of heights from the beginning of the film, and not only that, he fears their father and thinks nobody loves him. It is in his inability to love himself that his aggressive crusade against his father's will grow during the whole trip, and it is love that is revealed in his father's death, and could only be revealed by it, Figure 15. Therefore, the death of the father is seen as an act of love that frees Ivan from his self-hatred and makes Andrei perceive himself as truly the older brother. The death of the father is the moment than they experience self-awareness, and are "touched" by the world. They discover love of the other/Other through physical experience of his death. Boys start to sympathize and suffer-together-with their father in an act of saving his dead body. They are touched by the death and they respond to it in acts of care and responsibility, so they want to suffer now with their father in contrast to previous reluctance to be with the father and obey him. This suffering is depicted as carrying the body, and actually carrying the other (as a response to fathers lessons of taking care of themselves). 


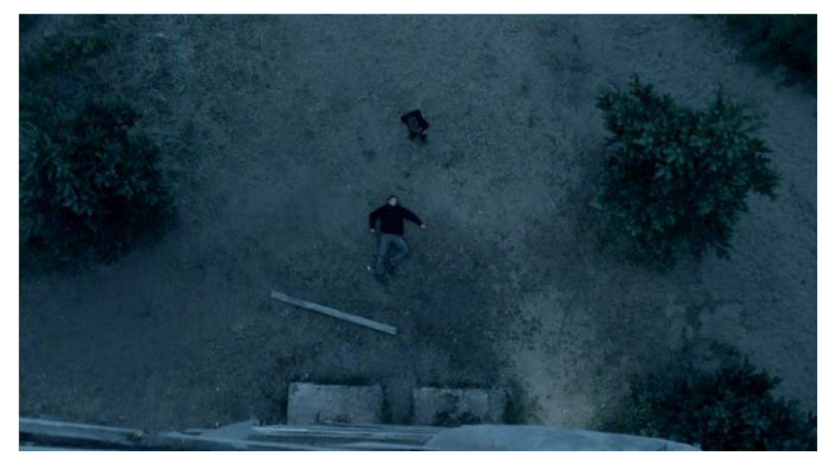

Figure 15. The Return (2003).

When the father knocks at the door, Ivan says "You are nobody". This corresponds to a religious "fight" between a desperate human being, seeing God as a harsh dictator stealing his freedom, and God himself. At the end of the film, God is interrupted by the self-sufficient phrase: "I can do it...", until God's sudden death. In this kind of experience, Ivan and Andrei face themselves and are transformed. It is in their father's "you" that they discover their own identity (and this otherness of the father is even more emphasized by his sudden visit and disappearance). The boys are formed by their father's otherness, and that they could not control him, for even in his death, he escapes their power and will. This otherness with the help of artistic parallels and film structure leads us to the understanding that it is not only the father as the other, but as the Other, too. The film implies that it is God who forms our self-identity through his revelation as God in his sacrifice.

The film also implies that co-suffering is important for self-perception, and it could be an answer to being "touched" by the other/Other. The possibility of co-suffering presumes bodily experience, which we observe in The Return [2] (they carry the body). We are loved, and by discovering this we are able to comprehend ourselves and love in return.

\subsection{Leviathan}

The problem of Leviathan [3] is that Nikolay is not looking for answers; he is not looking for reconciliation with Lilia or Roman. He ignores obvious problems. Even when Nikolay asks God "Why? Lord, for what reason?", he is not open to the priest's words. His questions to God are rhetorical.

Lilia is searching for the meaning of life and even for God, but she cannot find answers anywhere, so she is consumed by the emptiness she feels. Nikolay, Dimitriy and her friend Angela (having a friend with that name is rather ironic) all ignore Lilia. They do not want to hear her real questions and fears or understand her search for life. When Lilia talks with Dimitriy, he shows that he is not interested in talking about God and does not want to listen to any confessions. Nikolay does not even try to deal with his problems. Vodka and sex are blanket "solutions" for his problems, but they actually prove dehumanizing and depersonalizing. Leviathan [3] presents a quest for identity, even a quest for God.

The death of Lilia is a "touching" experience for Nikolay, but he is not able to see beyond his own struggles and expectations. It is in Lilia's death where Nikolay really understands that he lost her, though they have become distant long before. The experience of death of the other seems very important for Zvyagintsev, and the contact with a dead body seems to be, in a strange way, a sphere of self-identification, a moment of choice in forming self-consciousness and self-identity. It could be said that a death experience is vital for a "haptic" representation of the transcendent experience.

Probably the most consistent in his search for God is the local mayor, but it seems that those who guide him do not really help him in his search. In the end, all the characters are lost in their inability to connect with others and understand themselves. Even those present at the final Church liturgy feel the split between faith and works of the bishop and the mayor and the spiritual inadequacy of the service itself, Figures 16 and 17. 


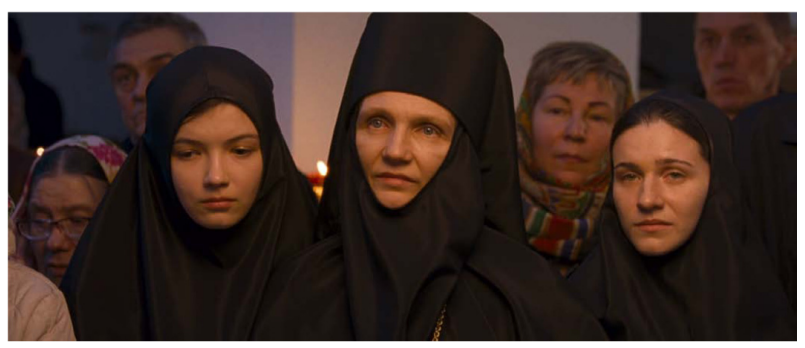

Figure 16. Leviathan (2014).

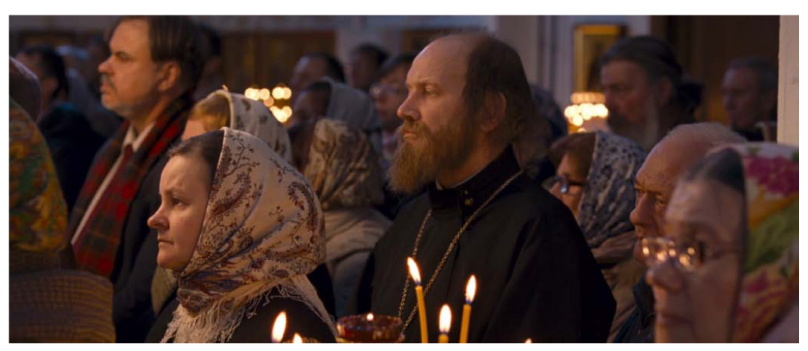

Figure 17. Leviathan (2014).

Leviathan [3] raises questions and presents problems of identity, but it reaches no resolution for the characters portrayed. Characters suffer, but they do not want to sympathize and co-suffer, they withdraw themselves from others, they suffer alone. Some may seem to deal with problems, but they actually do not want to meet the real other/Other and get into the reality of people they are living with. This could be combined with a fact that we see a lot of violence in the film, which illustrates alienation and desperation of characters (the inability to co-suffer leads into violence as emotional and physical experience). It presents the quest for love and being found in the kind gesture of the Other. Love is something characters are in quest of. It seems that Zvyagintsev is challenging the viewer to identify with the personal problems and quests depicted in films, and try to define one's own identity in real life. He uses double meaning of the bishop's preaching (as he says some right things, but amid a wrong context of his own wicked deeds) and some people's reaction to it as a challenge for us. It seems some of his films might suggest that Zvyagintsev leaves the experience of being touched by the other unresolved and attempts to provoke the self-awareness of the film viewer to change through his open-ended approach in this more recent film. He invites the viewer to co-suffer with his characters, to see ourselves in this painful traumatic film experience. The touch breaks through the cinematic body to challenge us, and it intrudes into the real life bodily experience of the other/Other and our self-perception.

\section{Conclusions}

Zvyagintsev's films and the theological themes articulated by John Panteleimon Manoussakis strengthen each other. When analyzed through the lenses of the interpersonal experience of space, time, and self-awareness, we see the metaphors of sight, hearing and touch applied as a personal encounter with the other/Other. The ideas of being seen and getting to know the other as a person, not as a concept, prove central in Zvyagintsev's work, as all of his films raise the question of the ability/inability to encounter the other/Other. Zvyagintsev's art is also often filled with a very special experience of time (within personal relationships or in a lack of personal relationships), so the concepts of kairos and the experience of exaiphnes may also be noted. Zvyagintsev's mythic experience of time and the way he depicts his stories also corresponds to Eucharistic time experience, and God's calling to turn one's attention to Him. Finally, an experience of the outer world as a way of discovering yourself in the context of God's revelation and through the world may be also traced to some scenes of Zvyagintsev's films. 
We see that the self-awareness of the main characters in Leviathan [3] is almost absent, yet he challenges the viewer to analyze their problematic experiences. The Return [2], on the other hand, portrays a story with an emphasis on a turning point in lives of the main characters. They seem to "see" and "hear" and "know" one another-and God Himself-through his sudden absence. To discover God through His lack of obvious presence is a crucial mystery in apophatic theology. Zvyagintsev invites us to see, hear, and feel it.

Acknowledgments: I want to acknowledge my mentor Timothy Noble, who has encouraged and supported me in my theological film studies.

Conflicts of Interest: The author declares no conflict of interest.

\section{References}

1. Julija Anochina. Dychanie Kamnja: Mir Fil'mov Andreja Zvjaginceva: Sbornik Statej i Materialov. Moskva: Novoe Literaturnoe Obozrenie, 2014.

2. Andrey Zvyagintsev. The Return. Berlin: Kino International, 2003.

3. Andrey Zvyagintsev. Leviathan. New York: Sony Pictures Classics, 2014.

4. John Panteleimon Manoussakis. "Toward a Fourth Reduction? " In After God: Richard Kearney and the Religious Turn in Continental Philosophy. Edited by John Panteleimon Manoussakis. New York: Fordham Press, 2006, pp. 21-33.

5. John Panteleimon Manoussakis. God after Metaphysics: A Theological Aesthetic. Bloomington: Indiana University Press, 2007.

6. Charles M. Stang. "Being Neither Oneself Nor Someone Else: The Apophatic Anthropology of Dionysus the Areopagite." In Apophatic Bodies: Negative Theology, Incarnation, and Relationality. Edited by Boesel Chris and Keller Catherine. New York: Fordham University Press, 2010, pp. 59-75.

7. Vivian C. Sobchack. The Address of the Eye: A Phenomenology of Film Experience. Princeton: Princeton University Press, 1999.

8. Vivian C. Sobchack. Carnal Thoughts: Embodiment and Moving Image Culture. Berkeley: University of California Press, 2004, pp. 302-3.

9. Joseph G. Kickasola. The Films of Krzysztof Kieślowski: The Liminal Image. New York: Continuum, 2004.

10. David Morgan. The Embodied Eye: Religious Visual Culture and the Social Life of Feeling. Berkeley: University of California Press, 2012, pp. 177-78.

11. Jennifer M. Barker. The Tactile Eye: Touch and the Cinematic Experience. Berkeley: University of California Press, 2009.

12. John Panteleimon Manoussakis. "Theophany and Indication: Reconciling Augustinian and Palamite Aesthetics." Modern Theology 26 (2010): 76-89. [CrossRef]

13. Jean-Luc Marion. In Excess: Studies of Saturated Phenomena. Translated by Robyn Horner and Vincent Berraud. New York: Fordham University Press, 2002, pp. 113-19.

14. Søren Kierkegaard, and Lowrie Walter. Fear and Trembling and the Sickness unto Death. Princeton: Princeton University Press, 2013, p. 128.

15. Andrey Zvyagintsev. Elena. Moscow: Non-Stop Productions, 2011.

16. Ambrosios Giakalis. Images of the Divine: The Theology of Icons at the Seventh Ecumenical Council, rev. ed. Leiden and Boston: Brill, 2005, pp. 59-60.

17. Denis J. Bekkering. “Leviathan." Journal of Religion \& Film, 2015. Available online: http://digitalcommons. unomaha.edu/jrf/vol19/iss1/45 (accessed on 25 September 2015).

18. John Panteleimon Manoussakis. "The Promise of the New and the Tyranny of the Same." In Phenomenology and Eschatology: Not yet in the Now. Edited by Neal DeRoo and John Panteleimon Manoussakis. Farnham and Burlington: Ashgate, 2009, pp. 69-89.

(C) 2016 by the author; licensee MDPI, Basel, Switzerland. This article is an open access article distributed under the terms and conditions of the Creative Commons Attribution (CC-BY) license (http://creativecommons.org/licenses/by/4.0/). 